\title{
Nutrient Solutions for Hydroponic Systems
}

\author{
Libia I. Trejo-Téllez and Fernando C. Gómez-Merino \\ Colegio de Postgraduados, Montecillo, Texcoco, State of Mexico \\ Mexico
}

\section{Introduction}

Hydroponic crop production has significantly increased in recent years worldwide, as it allows a more efficient use of water and fertilizers, as well as a better control of climate and pest factors. Furthermore, hydroponic production increases crop quality and productivity, which results in higher competitiveness and economic incomes.

Among factors affecting hydroponic production systems, the nutrient solution is considered to be one of the most important determining factors of crop yield and quality. This chapter aims to explain aspects related to plant nutrition and its effects on production of hydroponic crops, considering basic aspects such as nutrient solutions and their development through the years; components of nutrient solutions (macro and micronutrients), taking into account criteria of nutrimental essentiality in higher plants and their classification, as well as a brief description of their functions in plants; we define the concept of benefic element and its classification, and cite some examples of their addition to nutrient solutions. The concept of $\mathrm{pH}$ of the nutrient solution is also defined, as well as its effect on nutrimental availability; osmotic potential of the nutrient solution and its relationship with electric conductivity are discussed, besides their used units and their equivalences, and the influence of both factors on the nutrient uptake in plants; we highlight the importance of oxygenation in the nutrient solution; climate factors affecting nutrient solutions behaviour are also reported, emphasizing on temperature; formulation and preparation of nutrient solutions considering different fertilizer sources and water quality are described as well; finally, we raise topics related to the management of nutrient solutions depending on the species nutrimental needs and on the hydroponic system used, including flow diagrams and figures that facilitate readers comprehension of concepts and principles. Therefore, this chapter aims to be a practical guide to those interested in hydroponic crops, with a strong theoretical support.

\section{Nutrient solution}

A nutrient solution for hydroponic systems is an aqueous solution containing mainly inorganics ions from soluble salts of essential elements for higher plants. Eventually, some organic compounds such as iron chelates may be present (Steiner, 1968). An essential element has a clear physiological role and its absence prevents the complete plant life cycle (Taiz \& Zeiger, 1998). Currently 17 elements are considered essential for most plants, these are carbon, hydrogen, oxygen, nitrogen, phosphorus, potassium, calcium, magnesium, sulphur, iron, copper, zinc, manganese, molybdenum, boron, chlorine and nickel (Salisbury 
\& Ross, 1994). With the exception of carbon (C) and oxygen (O), which are supplied from the atmosphere, the essential elements are obtained from the growth medium. Other elements such as sodium, silicon, vanadium, selenium, cobalt, aluminum and iodine among others, are considered beneficial because some of them can stimulate the growth, or can compensate the toxic effects of other elements, or may replace essential nutrients in a less specific role (Trejo-Téllez et al., 2007). The most basic nutrient solutions consider in its composition only nitrogen, phosphorus, potassium, calcium, magnesium and sulphur; and they are supplemented with micronutrients.

The nutrient composition determines electrical conductivity and osmotic potential of the solution. Moreover, there are other parameters that define a nutrient solution as discussed below in detail.

\section{$2.1 \mathrm{pH}$ of the nutrient solution}

The $\mathrm{pH}$ is a parameter that measures the acidity or alkalinity of a solution. This value indicates the relationship between the concentration of free ions $\mathrm{H}^{+}$and $\mathrm{OH}^{-}$present in a solution and ranges between 0 and 14 .

In soil, the Troug diagram illustrates the $\mathrm{pH}$ effect on the availability of nutrients to plants (Fig. 1). Similarly, changing the $\mathrm{pH}$ of a nutrient solution affects its composition, elemental speciation and bioavailability. The term "speciation" indicates the distribution of elements among their various chemical and physical forms like: free ions, soluble complexes, chelates, ion pairs, solid and gaseous phases and different oxidation states (De Rijck \& Schrevens, 1998a).

An important feature of the nutrient solutions is that they must contain the ions in solution and in chemical forms that can be absorbed by plants, so in hydroponic systems the plant productivity is closely related with to nutrient uptake and the $\mathrm{pH}$ regulation (Marschner, 1995). Each nutrient shows differential responses to changes in $\mathrm{pH}$ of the nutrient solution as described below.

In the nutrient solution, $\mathrm{NH}_{3}$ only forms a complex with $\mathrm{H}^{+}$. For a $\mathrm{pH}$ range between 2 and $7, \mathrm{NH}_{3}$ is completely present as $\mathrm{NH}_{4}+$ (Fig. 2). Increasing the $\mathrm{pH}$ above 7 the concentration of $\mathrm{NH}_{4}{ }^{+}$decreases, while the concentration of $\mathrm{NH}_{3}$ augments (De Rijck \& Schrevens, 1999).

Tyson et al. (2007) in a study to determine the nitrification rate response in a perlite trickling biofilter (root growth medium) exposed to hydroponic nutrient solution, varying $\mathrm{NO}_{3}$ concentrations and two $\mathrm{pH}$ levels (6.5 and 8.5), founded that nitrification was significantly impacted by water $\mathrm{pH}$. The increased ammonia oxidation rate (1.75) compared to nitrite oxidation rate (1.3) at $\mathrm{pH} 8.5$ resulted in accumulation of $\mathrm{NO}_{2}{ }^{-}$to levels near those harmful to plants (observed peak of $4.2 \mathrm{mg} \mathrm{L}^{-1} \mathrm{NO}_{2}^{-}$). The potential for increased levels of un-ionized ammonia, which reduced plant nutrient uptake from micronutrient precipitation, are additional problems associated with $\mathrm{pH} 8.5$.

Phosphorus is an element which occurs in forms that are strongly dependent on environment $\mathrm{pH}$. In the root zone this element can be found as $\mathrm{PO}_{4}^{3-}, \mathrm{HPO}_{4}{ }^{2-}$, and $\mathrm{H}_{2} \mathrm{PO}_{4}^{-}$ ions; the last two ions are the main forms of $\mathrm{P}$ taken by plants. On inert substrates, the largest amount of $\mathrm{P}$ available in a nutrient solution is presented when its $\mathrm{pH}$ is slightly acidic ( $\mathrm{pH}$ 5). In alkaline and highly acidic solutions the concentration of $\mathrm{P}$ decreases in a 


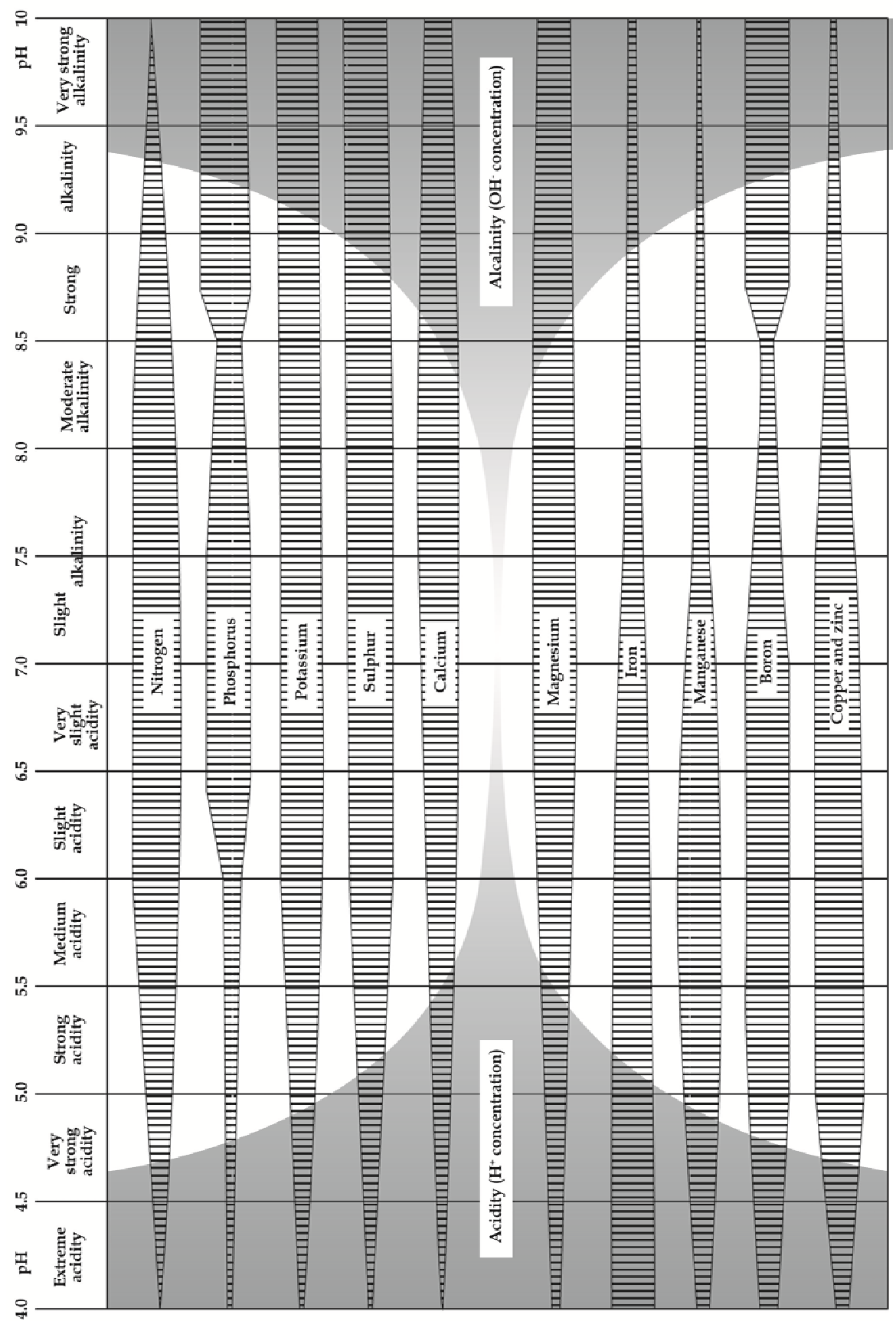

Fig. 1. Troug diagram of nutrient availability. Each nutrient is represented with a band; the thickness is proportional to the availability. 


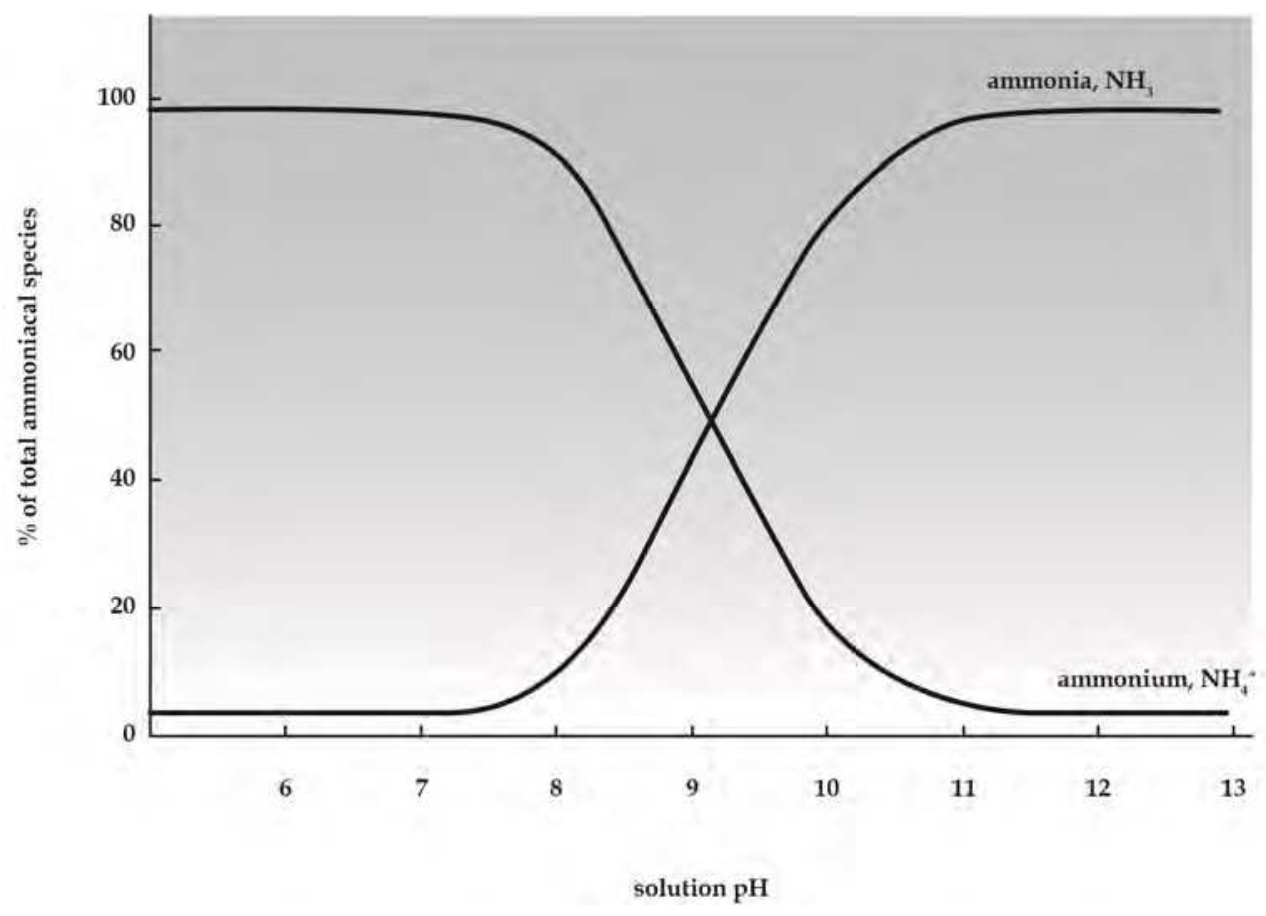

Fig. 2. Ammoniacal speciation in function of $\mathrm{pH}$.

significant way (Dyśko et al., 2008). Namely, with $\mathrm{pH} 5,100 \%$ of $\mathrm{P}$ is present as $\mathrm{H}_{2} \mathrm{PO}_{4}^{-}$; this form converts into $\mathrm{HPO}_{4}^{-2}$ at $\mathrm{pH} 7.3$ (pKa2), reaching $100 \%$ at $\mathrm{pH} 10$. The $\mathrm{pH}$ range that dominates the ion $\mathrm{H}_{2} \mathrm{PO}_{4}^{-2}$ on $\mathrm{HPO}_{4}^{-}$is between 5 and 6 (De Rijck \& Schrevens, 1997). The $\mathrm{pH}$-dependent speciation of $\mathrm{P}$ is showed in Fig. 3.

Potassium is almost completely present as a free ion in a nutrient solution with $\mathrm{pH}$ values from 2 to 9; only small amounts of $\mathrm{K}^{+}$can form a soluble complex with $\mathrm{SO}_{4}^{-2}$ or can be bound to $\mathrm{Cl}^{-}$(De Rijck \& Schrevens, 1998a). Like potassium, calcium and magnesium are available to plants in a wide range of $\mathrm{pH}$; however, the presence of other ions interferes in their availability due to the formation of compounds with different grade of solubility. As water naturally contains $\mathrm{HCO}_{3}$, this anion turns into $\mathrm{CO}_{3}{ }^{-2}$ when the $\mathrm{pH}$ is higher than 8.3 or to $\mathrm{H}_{2} \mathrm{CO}_{3}$ when it is less than 3.5; the $\mathrm{H}_{2} \mathrm{CO}_{3}$ is in chemical equilibrium with the carbon dioxide in the atmosphere. Thus at a $\mathrm{pH}$ above $8.3, \mathrm{Ca}^{2+}$ and $\mathrm{Mg}^{2+}$ ions easily precipitate as carbonates (Ayers \& Westcot, 1987). Also, as mentioned above, when the $\mathrm{pH}$ of the nutrient solution increases, the $\mathrm{HPO}_{4}{ }^{2-}$ ion predominates, which precipitates with $\mathrm{Ca}^{2+}$ when the product of the concentration of these ions is greater than 2.2, expressed in $\mathrm{mol} \mathrm{m}^{-3}$ (Steiner, 1984). Sulphate also forms relatively strong complexes with $\mathrm{Ca}^{2+}$ and $\mathrm{Mg}^{2+}$ (De Rijck \& Schrevens, 1998b). As $\mathrm{pH}$ increases from 2 to 9, the amount of $\mathrm{SO}_{4}{ }^{2-}$, forming soluble complexes with $\mathrm{Mg}^{2+}$ as $\mathrm{MgSO}_{4}$ and with $\mathrm{K}^{+}$as $\mathrm{KSO}_{4}^{-}$increases (De Rijck \& Schrevens, 1999).

Iron, copper, zinc, boron, and manganese, become unavailable at $\mathrm{pH}$ higher than 6.5 (Timmons et al., 2002; Tyson, 2007). In Triticum aestivum, the manganese precipitation on root surfaces was correlated with a plant-induced rise in $\mathrm{pH}$ of culture above 5.5 (Macfie \& 


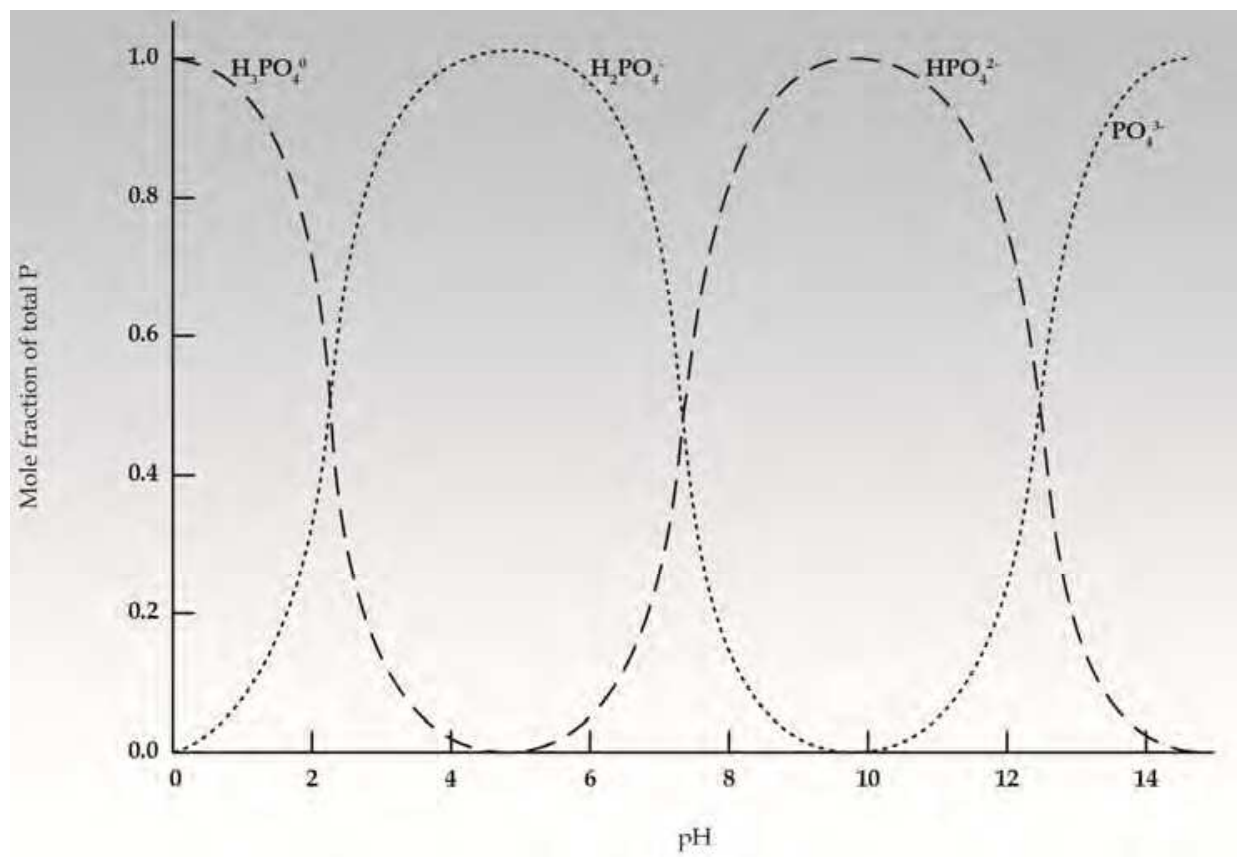

Fig. 3. Speciation of $\mathrm{P}$ depending on $\mathrm{pH}$.

Taylor, 1989). Boron is mainly uptaken by plants as boric acid, which is not dissociated until $\mathrm{pH}$ is close to 7; to greater $\mathrm{pH}$ values, boric acid accepts hydroxide ions to form anionic species (Tariq \& Mott, 2007) (Fig. 4).

Therefore, nutrient availability for plant uptake at $\mathrm{pH}$ above 7 may be restricted due to precipitation of $\mathrm{Fe}^{2+}, \mathrm{Mn}^{2+}, \mathrm{PO}_{3}{ }^{-4}, \mathrm{Ca}^{2+}$ and $\mathrm{Mg}^{2+}$ to insoluble and unavailable salts (Resh, 2004). The proper $\mathrm{pH}$ values of nutrient solution for the development of crops, lies between 5.5 and 6.5 .

\subsection{Electrical conductivity of the nutrient solution}

The total ionic concentration of a nutrient solution determines the growth, development and production of plants (Steiner, 1961). The total amount of ions of dissolved salts in the nutrient solution exerts a force called osmotic pressure (OP), which is a colligative property of the nutrient solutions and it is clearly dependent of the amount of dissolved solutes (Landowne, 2006). Also, the terms solute potential or osmotic potential are widely used in nutrient solution, which represent the effect of dissolved solutes on water potential; solutes reduce the free energy of water by diluting the water (Taiz \& Zeiger, 1998). Thus, the terms osmotic pressure and osmotic potential can be used interchangeably, still important considering the units that are used, commonly atm, bar and MPa (Sandoval et al., 2007).

An indirect way to estimate the osmotic pressure of the nutrient solution is the electrical conductivity (EC), an index of salt concentration that defines the total amount of salts in a solution. Hence, EC of the nutrient solution is a good indicator of the amount of available 


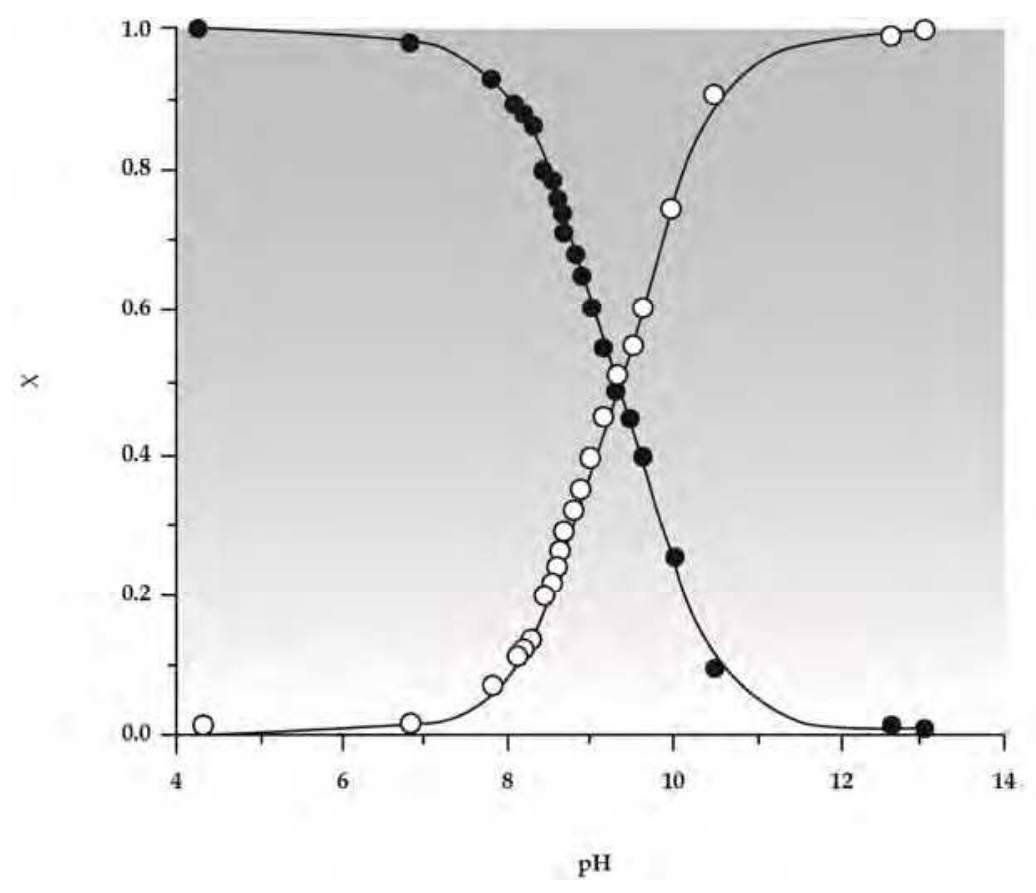

Fig. 4. Transformation of boric acid (black circles) and anion forms of boric acid (white circles) as a function of $\mathrm{pH}$ (Bishop et al., 2004).

ions to the plants in the root zone (Nemali \& van Iersel, 2004). Estimation of the osmotic pressure of a nutrient solution from EC can be done by using the following empirical relations (Sandoval, 2007):

$$
\begin{gathered}
\mathrm{OP}(\mathrm{atm})=0.36 \times \mathrm{EC}\left(\text { in dS } \mathrm{m}^{-1} \text { at } 25^{\circ} \mathrm{C}\right) \\
\mathrm{OP}(\text { bar })=-0.36 \times \mathrm{EC}\left(\text { in } \mathrm{dS} \mathrm{m}^{-1} \text { at } 25^{\circ} \mathrm{C}\right) \\
\mathrm{OP}(\mathrm{MPa})=\mathrm{OP} \text { (bars) } \times 0.1
\end{gathered}
$$

The ions associated with $\mathrm{EC}$ are $\mathrm{Ca}^{2+}, \mathrm{Mg}^{2+}, \mathrm{K}^{+}, \mathrm{Na}^{+}, \mathrm{H}^{+}, \mathrm{NO}_{3}{ }^{-}, \mathrm{SO}_{4}{ }^{2-}, \mathrm{Cl}^{-}, \mathrm{HCO}_{3}{ }^{-}, \mathrm{OH}^{-}$ (United States Departament of Agriculture [USDA], 2001). The supply of micronutriments, namely $\mathrm{Fe}, \mathrm{Cu}, \mathrm{Zn}, \mathrm{Mn}, \mathrm{B}, \mathrm{Mo}$, and $\mathrm{Ni}$, are very small in ratio to the others elements (macronutrients), so it has no a significant effect on EC (Sonneveld \&Voogt, 2009).

The ideal EC is specific for each crop and dependent on environmental conditions (Sonneveld \&Voogt, 2009); however, the EC values for hydroponic systems range from 1.5 to $2.5 \mathrm{ds} \mathrm{m}^{-1}$. Higher EC hinders nutrient uptake by increasing osmotic pressure, whereas lower EC may severely affect plant health and yield (Samarakoon et al., 2006). The decrease in water uptake is strongly and linearly correlated to EC (Dalton et al., 1997). Table 1 shows the classification of crops in function of salinity tolerance.

As noted in Table 1, some crops can grow with high levels of EC and even a proper management of EC of the nutrient solution can provide and effective tool to improve 


\begin{tabular}{|l|l|l|}
\hline \multicolumn{1}{|c|}{ Salinity group } & \multicolumn{1}{|c|}{$\begin{array}{c}\text { Threshold EC, } \\
\text { dS } \text { m }^{-1}\end{array}$} & \multicolumn{1}{c|}{ Example of crops } \\
\hline Sensitive & 1.4 & lettuce, carrot, strawberry, onion \\
\hline Moderately sensitive & 3.0 & $\begin{array}{l}\text { broccoli, cabbage, tomato, cucumber, } \\
\text { radish, pepper }\end{array}$ \\
\hline Moderately tolerant & 6.0 & soybean, ryegrass \\
\hline Tolerant & 10.0 & bermuda-grass, sugarbeet, cotton \\
\hline
\end{tabular}

Table 1. Threshold EC for salinity groups and example of crops (Jensen, 1980; Tanji, 1990).

vegetable quality (Gruda, 2009). In particular, parameters of fruit quality such as soluble solids content, titratable acidity and dry matter augmented by increasing EC level of

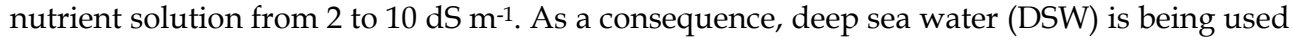
for nutrient solution due to its high amount of $\mathrm{Na}^{+}, \mathrm{Mg}^{2+}, \mathrm{K}^{+}$and $\mathrm{Ca}^{2+}$ (Chadirin et al., 2007).

\subsection{Composition of the nutrient solution}

As previously stated, nutrient solutions usually contain six essential nutrients: N, P, S, K, Ca and $\mathrm{Mg}$. Thereby Steiner created the concept of ionic mutual ratio which is based on the mutual ratio of anions: $\mathrm{NO}_{3}^{-}, \mathrm{H}_{2} \mathrm{PO}_{4}^{-}$and $\mathrm{SO}_{4}{ }^{2-}$, and the mutual ratio of cations $\mathrm{K}^{+}, \mathrm{Ca}^{2+}$, $\mathrm{Mg}^{2+}$. Such a relationship is not just about the total amount of each ion in the solution, but in the quantitative relationship that keep the ions together; if improper relationship between them take place, plan performance can be negatively affected(Steiner, 1961, 1968).

In this way, the ionic balance constraint makes it impossible to supply one ion without introducing a counter ion. A change in the concentration of one ion must be accompanied by either a corresponding change for an ion of the opposite charge, a complementary change for other ions of the same charge, or both (Hewitt, 1966).

When a nutrient solution is applied continuously, plants can uptake ions at very low concentrations. So, it has been reported than a high proportion of the nutrients are not used by plants or their uptake does not impact the production. For example, it was determined that in anthurium, $60 \%$ of nutrients are lost in the leachate (Dufour \& Guérin, 2005); but in closed systems, however, the loss of nutrients from the root environment is brought to a minimum (Voogt, 2002). Also it has been shown that the concentration of nutrient solution can be reduced by $50 \%$ without any adverse effect on biomass and quality in gerbera (Zheng et al., 2005) and geranium (Rouphael et al., 2008). Accordingly, Siddiqi et al. (1998) reported no adverse effect on growth, fruit yield and fruit quality in tomato when reduction of macronutrient concentrations to $50 \%$ of the control level as well as cessation of replenishment of the feed solution for 16 days after 7 months of growth at control levels were applied. However, it is expected that in particular situations, too low concentrations do not cover the minimum demand of certain nutrients.

On the other hand, high concentrated nutrient solutions lead to excessive nutrient uptake and therefore toxic effects may be expected. Conversely, there are evidences of positive effects of high concentrations of nutrient solution. In salvia, the increase of Hoagland concentration at $200 \%$ caused that plants flowered 8 days previous to the plants at low concentrations, increasing total dry weight and leaf area (Kang \& van Iersel, 2004). Likewise, high levels of $\mathrm{K}^{+}$ 
in the nutrient solution (14.2 meq L-1 vs 3.4 meq $\left.\mathrm{L}^{-1}\right)$ increased fruit dry matter, total soluble solids content and lycopene concentration of tomato (Fanasca et al., 2006).

The explanation of these apparent controversial responses is the existence of optimal concentrations of certain nutrients in a solution for a culture under special environmental conditions as well as their relative proportions and not their absolute concentrations as determining factors (Juárez et al., 2006). In order to prevent contradictory observations, Dufour \& Guérin (2005) recommend: a) to monitor the availability of nutrients through changes in the ionic composition of the substrate by analysis of percolate, and b) to asses plant nutrient uptake by nutrient content analysis in leaves. Moreover, Voogt (2002) indicates that the nutrient solution composition must reflect the uptake ratios of individual elements by the crop and as the demand between species differs, the basic composition of a nutrient solution is specific for each crop. It must also be taken into account that the uptake differs between elements and the system used. For instance, in open-systems with free drainage, much of the nutrient solution is lost by leachate.

There are several formulations of nutrient solutions. Nevertheless, most of them are empirically based. Table 2 comprises some of them.

\begin{tabular}{|l|l|l|l|l|}
\hline \multicolumn{1}{|c|}{ Nutrient } & $\begin{array}{c}\text { Hoagland \& Arnon } \\
\text { (1938) }\end{array}$ & \multicolumn{1}{|c|}{$\begin{array}{c}\text { Hewitt } \\
(\mathbf{1 9 6 6 )}\end{array}$} & Cooper (1979) & Steiner (1984) \\
\hline & $\mathrm{mg} \mathrm{L}^{-1}$ & 168 & $200-236$ & 168 \\
\hline $\mathrm{N}$ & 210 & 41 & 60 & 31 \\
\hline $\mathrm{P}$ & 31 & 156 & 300 & 273 \\
\hline $\mathrm{K}$ & 234 & 160 & $170-185$ & 180 \\
\hline $\mathrm{Ca}$ & 160 & 36 & 50 & 48 \\
\hline $\mathrm{Mg}$ & 34 & 48 & 68 & 336 \\
\hline $\mathrm{S}$ & 64 & 2.8 & 12 & $2-4$ \\
\hline $\mathrm{Fe}$ & 2.5 & 0.064 & 0.1 & 0.02 \\
\hline $\mathrm{Cu}$ & 0.02 & 0.065 & 0.1 & 0.11 \\
\hline $\mathrm{Zn}$ & 0.05 & 0.54 & 2.0 & 0.62 \\
\hline $\mathrm{Mn}$ & 0.5 & 0.54 & 0.3 & 0.44 \\
\hline $\mathrm{B}$ & 0.5 & 0.04 & 0.2 & Not considered \\
\hline $\mathrm{Mo}$ & 0.01 & &
\end{tabular}

Table 2. Concentration ranges of essential mineral elements according to various authors (adapted from Cooper, 1988; Steiner, 1984; Windsor \& Schwarz, 1990).

\subsection{Temperature of the nutrient solution}

The temperature of the nutrient solution influences the uptake of water and nutrients differentially by the crop.

Two nutrient solution temperatures (cold and warm solution, 10 and $22{ }^{\circ} \mathrm{C}$, respectively) were evaluated during two flowering events of rose plants (Rosa $\times$ hybrida cv. Grand Gala). 
Generally, cold solution increased $\mathrm{NO}_{3}{ }^{-}$uptake and thin-white roots production, but decreased water uptake. Nutrient solution temperature also had an effect on the photosynthetic apparatus. In general terms, the effective quantum yield and the fraction of open PSII reaction centres were higher in rose plants grown at cold solution (Calatayud et al., 2008).

In spinach seedlings, three temperatures of irrigation water $\left(24,26\right.$ and $\left.28{ }^{\circ} \mathrm{C}\right)$ were evaluated during 8 weeks. Leaf length, leaf number and total fresh and dry biomass weights per plant were higher in plants grown at elevated temperatures, with optimum growth being recorded at $28^{\circ} \mathrm{C}$ (Nxawe et al., 2009).

In tomato plants, rates of water and nutrients uptake by roots (which varied depending on solar radiation) were studied. High solution temperature $\left(35^{\circ} \mathrm{C}\right)$ produced effects in the short and long-term. In the short-term, water and nutrients uptake were activated through a decrease in water viscosity, and membrane transport was affected. In the long term, oxygen solubility was reduced, while enzymatic oxidization of phenolic compounds in root epidermal and cortex tissues were stimulated, but nutrient concentration in root xylem sap diminished, and the root xylem sap concentration of $\mathrm{N}, \mathrm{K}, \mathrm{Ca}$ became lower than those in the nutrient solution (Falah et al., 2010).

Graves (1983) observed that at temperatures below $22{ }^{\circ} \mathrm{C}$ the dissolved oxygen in the nutrient solution is sufficient to cover the demand of this element in tomato plants. Nevertheless, the requirement diminished as a consequence of a reduction in a number of physiological processes, including respiration, which further impacts plant growth. Conversely, temperatures over $22^{\circ} \mathrm{C}$, oxygen demand is not covered by the nutrient solution as higher temperatures increase the diffusion of this gas. At high temperatures of the nutrient solution an increased vegetative growth to a greater extent than desirable is observed, which reduces fructification.

To assess the importance of temperature on the solubility of oxygen, Table 3 depicts data for temperatures that are usually filed within greenhouses, so that temperature has a direct relationship to the amount of oxygen consumed by the plant and reverse relationship with dissolved oxygen from the nutrient solution.

\begin{tabular}{|l|l|}
\hline \multicolumn{1}{|c|}{ Temperature, ${ }^{\circ} \mathbf{C}$} & \multicolumn{1}{|c|}{ Oxygen solubility, mg L $^{-1}$ of pure water } \\
\hline 10 & 11.29 \\
\hline 15 & 10.08 \\
\hline 20 & 9.09 \\
\hline 25 & 8.26 \\
\hline 30 & 7.56 \\
\hline 35 & 6.95 \\
\hline 40 & 6.41 \\
\hline 45 & 5.93 \\
\hline
\end{tabular}

Table 3. Solubility of oxygen in water pure at various temperatures at $760 \mathrm{~mm} \mathrm{Hg}$ of atmospheric pressure. 


\section{Nutrient solution management}

Soilless cultivation allows a more accurate control of environmental conditions that offers possibilities for increasing production and improving quality of crops. In particular, in the nutrient solution parameters such as temperature, $\mathrm{pH}$, electrical conductivity, oxygen content, among others can be manipulated. If these parameters are not controlled properly and in timing, advantage can be translated into disadvantages. Then, several ways to control some parameters of the nutrient solution are to be reviewed in the following.

\section{$3.1 \mathrm{pH}$ regulation}

As mentioned above, the $\mathrm{pH}$ value determines the nutrient availability for plants. Accordingly, its adjustment must be done daily due to the lower buffering capacity of soilless systems (Urrestarazu, 2004).

The changes in the $\mathrm{pH}$ of a nutrient solution depending on the difference in the magnitude of nutrient uptake by plants, in terms of the balance of anions over cations. When the anions are uptaken in higher concentrations than cations, for example nitrate, the plant excretes $\mathrm{OH}^{-}$or $\mathrm{HCO}_{3}{ }^{-}$anions, to balance the electrical charges inside, which produces increasing in the $\mathrm{pH}$ value. This process is called physiological alkalinity (Marschner, 1995).

Hence, incorporation of ammonium as $\mathrm{N}$ source in the nutrient solution regulates the $\mathrm{pH}$ and therefore nutrient availability is ensured. Breteler \& Smit (1974) reported that ammonium depressed the $\mathrm{pH}$ of nutrient solution even in the presence of nitrate. In rose plants, the addition of ammonium in a nutrient solution containing nitrate produced a total nitrogen uptake increase during shoot elongation; and an increase in P concentration in the roots (Lorenzo et al., 2000). The proportion of total nitrogen is added to the nutrient solution as ammonium is dependent on the crop.

On other hand, the chemical adjustment is widely used, namely the addition of acids to reduce the $\mathrm{pH}$ value. The $\mathrm{pH}$ is closely related to the concentration of $\mathrm{HCO}_{3}{ }^{-}$and $\mathrm{CO}_{3}{ }^{2-}$; when an acid is applied, the $\mathrm{CO}_{3}{ }^{2-}$ ion is transformed to $\mathrm{HCO}_{3}^{-}$, and then $\mathrm{HCO}_{3}$ - is converted into $\mathrm{H}_{2} \mathrm{CO}_{3}$. Carbonic acid is partially dissociated in $\mathrm{H}_{2} \mathrm{O}$ and $\mathrm{CO}_{2}$ (De Rijck \& Schrevens, 1997). Regulation of $\mathrm{pH}$ is normally carried out by using nitric, sulphuric or phosphoric acid, and such acids can be used either individually or combined.

\subsection{Electrical conductivity management}

Electrical conductivity (EC) is modified by plants as they absorb nutrients and water from the nutrient solution. Therefore, a decrease in the concentration of some ions is and an increase in the concentration of others is observed simultaneously, both in close and open systems. For example, in a closed hydroponic system with a rose crop, the composition of the nutrient solution in the tank was measured. It was observed that the concentration of Fe decreased very fast, while that of $\mathrm{Ca}^{2+}, \mathrm{Mg}^{2+}$ and $\mathrm{Cl}^{-}$increased; moreover, concentrations of $\mathrm{K}^{+}, \mathrm{Ca}^{2+}$ and $\mathrm{SO}_{4}^{2-}$ did not reach critical levels (Lykas et al., 2001). Instead, in an open system with recirculation of nutrient solution, an increase in the EC value due to the accumulation of high levels of some ions like bicarbonates, sulphates and chlorides is observed (Zekki et al. 1996). So, the recycling of nutrient solution represents a point of discussion. Moreover, the substrates can retain ions and consequently the EC increases. To reduce the salt 
accumulation in substrates, the controlled leaching with water of good quality is an alternative (Ansorena, 2004). The use of mulching with polyethylene or polypropylene sheet reduces the water consumption, increases the calculated water use efficiency and decreases the EC of the substrate; so the mulching is an alternative to control of EC too (Farina et al., 2003).

On the one hand, positive evidences of nutrient solutions reuse are reported, which necessarily involves regulation of the EC. Therefore, recycling and reuse of solutions is a trend in searching for sustainable agricultural production systems (Andriolo et al., 2006). Brun et al. (2001) reported recycling systems based on EC control, consisting of adding a water complement to the drainage to decrease the $\mathrm{EC}$ and a complement nutrient solution to obtain the desired EC. Carmassi et al. (2003) developed a simple model for the changes in ion concentration and EC of recirculating nutrient solution in closed-loop soilless culture on the basis of balance equation for nutrient uptake by hydroponically-grown plants. In this model, the crop evapotranspiration is compensated by refilling the mixing tank with complete nutrient solution.

Recently, an in situ optimal control method of nutrient solution composition has been proposed. Instead of modeling the correlations between greenhouse vegetable growth and nutrient solution, this method is based on Q-learning searches for optimal control policy through systematic interaction with the environment (Chen et al., 2011).

Even though, Bugbee (2004) indicates that the monitoring ions in solution is not always necessary. In fact, the rapid depletion of some nutrients often causes people to add toxic amounts of nutrients to the solution. Besides, it has been demonstrated the existence of a wide cultivable microbial community in the nutrient solution before recycling and recirculation, which supports the necessity of disinfecting nutrient solutions used in soilless cultivation systems, during the recycling process, in order to ensure crop sanitation and avoiding plant disease spreading (Calmin et al., 2008).

\subsection{Temperature control}

The temperature of the nutrient solution has a direct relation to the amount of oxygen consumed by plants, and an inverse relation to the oxygen dissolved in it, as it was previously indicated. Temperature also affects solubility of fertilizer and uptake capacity of roots, being evident the importance of controlling this variable especially in extreme weathers. Each plant species has a minimum, optimum, and maximum temperature for growth, which requires the implementation of heating or cooling systems for balancing the nutrient solution temperature.

The underground water pipe system for energy-saving control of nutrient solution temperature consists of a large-sized pipe filled with water under the ground, and a unit for circulating the nutrient solution between the cultivation bed and the underground water pipe. The temperature condition in the underground water pipe $1.5 \mathrm{~m}$ below the ground surface is stable as compared to that in greenhouses which excessively high temperatures in summer and low in winter. During the circulation, heat can be exchanged between the nutrient solution and the water stored in the underground water pipe. Furthermore, this circulation warmed the nutrient solution excessively chilled in cold winter nights (Hidaka et al., 2008). 
Nam et al. (1996) evaluated the cooling capacities of three different systems, which used either polyethylene or stainless tube in the solution tank, or a counter flow type with double pipes, having 41,70 or $81 \%$ of cooling load in a hydroponic greenhouse, respectively.

Villela et al. (2004) evaluated the cooling of the nutrient solution at about $12{ }^{\circ} \mathrm{C}$ by using a heating exchange device on the productivity of two varieties of strawberry. The cooling of the nutrient solution conferred better productivity of Sweet Charlie variety; whilst it didn't cause any effects over the Campinas variety.

As stated above, deep sea water (DSW) can be used in the preparation of nutrient solutions due to its nutrient content. Likewise, it is one alternative for nutrient cooling systems in hot season due to its low temperature. Cold DSW pumped inside pipe through cultivation bed might decrease temperature of nutrient solution by heat exchange between nutrient solution and DSW. For environment reason, after being used for cooling system, DSW that contained abundant nutrient can be used as nutrient supplement for tomato plant by diluting into standard nutrient solution. It is suggested that DSW might increase fruit quality because of its enrichment of nutrient solution (Chadirin et al., 2006).

\subsection{Oxygenation of nutrient solution}

The consumption of $\mathrm{O}_{2}$ increases when the temperature of nutrient solution increases too. Consequently, it produces an increase in the relative concentration of $\mathrm{CO}_{2}$ in the root environment if the root aeration is not adequate (Morard \& Silvestre, 1996).

The concentration of oxygen in the nutrient solution also depends on crop demand, being higher when the photosynthetic activity increases (Papadopoulous et al., 1999). A decrease bellow 3 or $4 \mathrm{mg} \mathrm{L}^{-1}$ of dissolved oxygen, inhibits root growth and produces changes to a brown color, which can be considered as the first symptom of the oxygen lack (Gislerød \& Kempton, 1983).

Nonetheless, substrates under long cultivation periods usually present increase of organic matter content and microorganism activity, which could lead to an increase of the competition for oxygen in the root environment. Yet, roots are densely matted within the substrate, which alters diffusion and supply of oxygen (Bonachela et al., 2010).

The supply of pure, pressurized oxygen gas to the nutrient solution is an oxygen-enriched method often used for research purposes, and it is called oxyfertigation (Chun \& Takakura, 1994).

Bonachela et al. (2010) evaluated the response to oxygen enrichment of nutrient solution in of autumn-winter sweet pepper and spring melon crops grown on rockwool slabs and perlite grow-bags, compared to non-enriched crops. The pressurized oxygen gas was dissolved in the nutrient solution during each irrigation with a gas injector within the irrigation pipe. The use of inexpensive systems of substrate oxygen enrichment should be restricted to rockwool substrates and to crop periods when a high oxygen demand coincides with low oxygen availability, such as the period from melon flowering phase.

The supply of potassium peroxide as an oxygen generator on vegetable crops grown in commercial substrates once a week was evaluated in sweet pepper, melon and cucumber. Results indicated that the application of potassium peroxide at a concentration of $1 \mathrm{~g} \mathrm{~L}^{-1}$ is the 
best fraction to use in soilless culture. The treatment with potassium peroxide increases the yield of sweet pepper and melon in 20 and 15\% respectively, in comparison to the control, whereas there was no significant difference in cucumber yield (Urrestarazu \& Mazuela, 2005).

\section{Preparation of nutrient solution}

\subsection{Nutrient solution design}

Hansen (1978) indicates that the addition of plant nutrients to hydroponic systems may be performed according to the plant nutrient requirement. Application of nutrients may be performed according to analyses of a specific crop stage that may describe the consumption of the various typical nutrients of the particular crop or by means of analyses of the total plant needs quantitatively adjusted to the rate of growth and the amounts of water supplied. Thus, the composition and concentration of the nutrient solution are dependent on culture system, crop development stage, and environmental conditions (Coic, 1973; Steiner, 1973).

Likewise, Steiner (1968) proposed that in soilless cultures any ionic ratio and any total concentration of ions can be given, as precipitation limits for certain combinations of ions are considered. Thus, the selection the concentration of a nutrient solution should be such that water and total ions are absorbed by the plant in the same proportion in which those are present in the solution.

Steiner (1961) developed a method to calculate a formula for the composition of a nutrient solution, which satisfies certain requirements. Later on he evaluated five different ratios of $\mathrm{NO}_{3}$ :anions $\left(\mathrm{NO}_{3}{ }^{-}+\mathrm{H}_{2} \mathrm{PO}_{4}{ }^{-}+\mathrm{SO}_{4}{ }^{2-}\right)$ and three of $\mathrm{K}^{+}$:cations $\left(\mathrm{K}^{+}+\mathrm{Ca}^{2+}+\mathrm{Mg}^{2+}\right)$, combining also the two groups, resulting in a full factorial design (Fig. 5); all solutions had the same osmotic pressure and $\mathrm{pH}$ value. In this system, the relative concentration of $\mathrm{K}^{+}$increases at the expense of $\mathrm{Ca}^{2+}$ and $\mathrm{Mg}^{2+}$ concentrations. Furthermore, the ratio 3:1 between $\mathrm{Ca}^{2+}$ and $\mathrm{Mg}^{2+}$ is constant. Similarly, the ratio $\mathrm{H}_{2} \mathrm{PO}_{4}^{-:}: \mathrm{SO}_{4}{ }^{2-}(1: 9)$ is constant, while the changes in the $\mathrm{NO}_{3}$ - concentration are produced at expense of the $\mathrm{H}_{2} \mathrm{PO}_{4}^{-}$and $\mathrm{SO}_{4}{ }^{2}$ - concentrations (Steiner, 1966).

On the other hand, Van Labeke et al. (1995) studied Eustoma grandiflorum responses to different nutrient solutions differing in ion ratios using an experimental as a $\{3.1\}$ simplex centroid design, one in the cation factor-space and the other in the anion factor-space, which is depicted in Fig. 6. Then, De Rijck \& Schrevens (1998c) investigated the effects of the mineral composition of the nutrient solution and the moisture content of the substrate on the mineral content of hydroponically grown tomato fruits, using "design and analysis of mixture systems", a $\{3.1\}$ simplex lattice design extended with the overall centroid set-up in the cation factor-space $\left(\mathrm{K}^{+}, \mathrm{Ca}^{2+}\right.$ and $\left.\mathrm{Mg}^{2+}\right)$ of the nutrient solution. For each nutritional composition two moisture contents (40 and $80 \%$ of volume) of the substrates were investigated.

After this short sample illustrates some aspects to be considered in the preparation of nutrient solutions.

\subsection{Water quality}

According to Tognoni et al. (1998), water quality in hydroponics can be limited to the concentrations of specific ions and phytotoxic substances relevant for plant nutrition as well as the presence of organisms and substances that can clog the irrigation systems. 

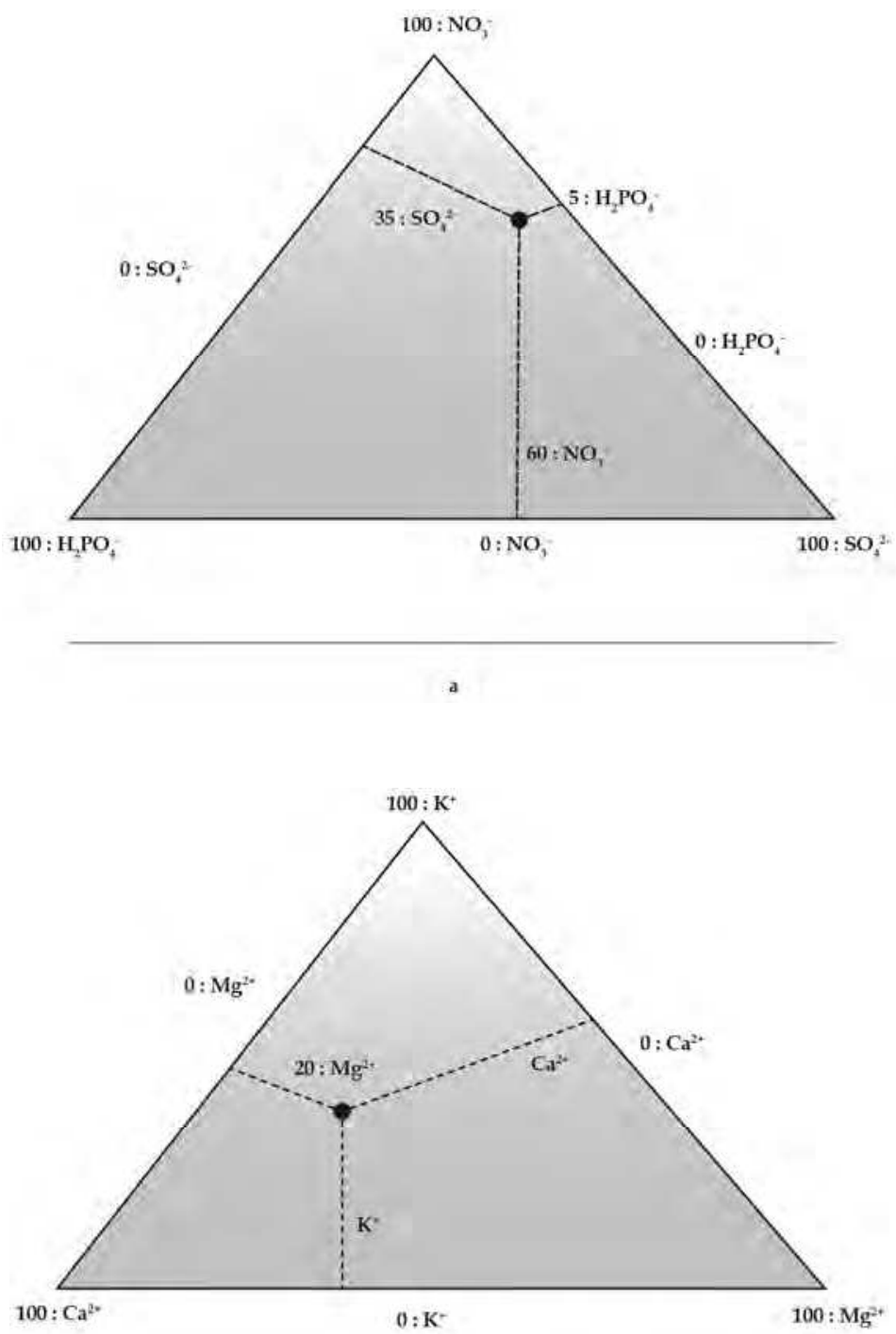

b

Fig. 5. Proposed ratios $\mathrm{NO}_{3}{ }^{-}$:anions $\left(\mathrm{NO}_{3}^{-}+\mathrm{H}_{2} \mathrm{PO}_{4}^{-}+\mathrm{SO}_{4}{ }^{2-}\right)\left(\right.$ a) and $\mathrm{K}^{+}$:cations $\left(\mathrm{K}^{+}+\mathrm{Ca}^{2++} \mathrm{Mg}^{2+}\right)$ (b) by Steiner (1966). 


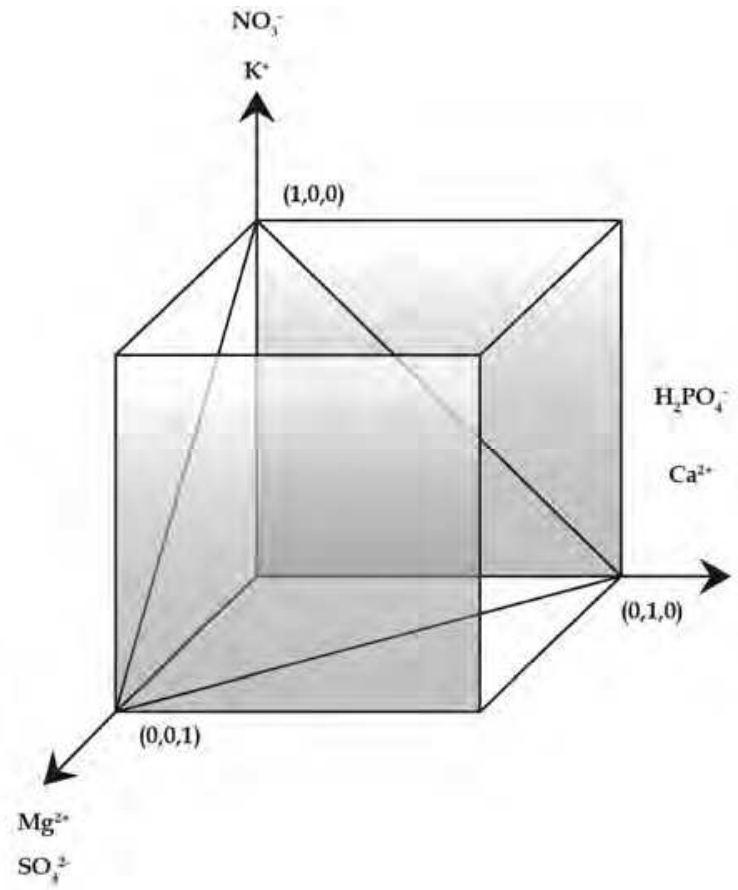

Fig. 6. Experimental $\{3.1\}$ simplex centroid design used by Van Lecke et al. (2006).

Regarding the presence of organisms both in water for preparing nutrient solution and in recirculating nutrient solution, its control can be achieved by heat treatment, UV radiation and membrane filtration. However, cheaper chemical treatments as sodium hypochlorite, chlorine dioxide and copper silver ionization may partly solve the pathogen problem; with the disadvantages that introduce a potential accumulation of other elements in closed systems (van Os, 2010).

It is necessary to carry out a chemical analysis of water to be used in the nutrient solution. Knowing the kind and concentration of ions allows identifying on the one hand, those that are needed in the nutrient solution and therefore can be subtracted from the original formulation; and on the other hand, to take decisions about ions not needed in the nutrient solution.

As previously mentioned, DSW can be used for preparing nutrient solutions. Chadirin et al. (2007) reported that plants treated with circulated water having an EC of $20 \mathrm{dS} \mathrm{m}^{-1}$ produced tomatoes with highest soluble solids, $8.0 \%$ Brix or increased yield in $30 \%$ in comparison to the control. Nevertheless, Pardossi et al. (2008) showed that nutrient solution with high EC $\left(9 \mathrm{dS} \mathrm{m}^{-1}\right)$ had no important effects on both crop yield and fruit quality.

\subsection{Fertilizer source for nutrient solution}

Table 4 has a list of commonly used fertilizers and acids in hydroponics, as well as some characteristics of interest for plant nutrition applications. 


\begin{tabular}{|l|l|l|c|}
\hline \multicolumn{1}{|c|}{ Fertilizers } & \multicolumn{1}{|c|}{ Formula } & \multicolumn{1}{|c|}{$\begin{array}{c}\text { Nutrient } \\
\text { percentage }\end{array}$} & $\begin{array}{c}\text { Solubility, } \text { L L}^{-1} \text { at } \\
\mathbf{2 0}{ }^{\circ} \mathbf{C}\end{array}$ \\
\hline Calcium nitrate & $\mathrm{Ca}\left(\mathrm{NO}_{3}\right)_{2} 5 \mathrm{H}_{2} \mathrm{O}$ & $\mathrm{N}: 15.5 ; \mathrm{Ca}: 19$ & 1290 \\
\hline Potassium nitrate & $\mathrm{KNO}_{3}$ & $\mathrm{~N}: 13 ; \mathrm{K}: 38$ & 316 \\
\hline Magnesium nitrate & $\mathrm{Mg}\left(\mathrm{NO}_{3}\right)_{2} 6 \mathrm{H}_{2} \mathrm{O}$ & $\mathrm{N}: 11 ; \mathrm{Mg}: 9$ & 760 \\
\hline Ammonium nitrate & $\mathrm{NH}_{4} \mathrm{NO}_{3}$ & $\mathrm{~N}: 35$ & 1920 \\
\hline $\begin{array}{l}\text { Monopotassium } \\
\text { phosphate }\end{array}$ & $\mathrm{KH}_{2} \mathrm{PO}_{4}$ & $\mathrm{P}: 23 ; \mathrm{K}: 28$ & 226 \\
\hline $\begin{array}{l}\text { Monoammonium } \\
\text { phosphate }\end{array}$ & $\mathrm{NH}_{4} \mathrm{H}_{2} \mathrm{PO}_{4}$ & $\mathrm{~N} ; 12 ; \mathrm{P}: 60$ & 365 \\
\hline Potassium sulphate & $\mathrm{K}_{2} \mathrm{SO}_{4}$ & $\mathrm{~K}: 45 ; \mathrm{S}: 18$ & 111 \\
\hline Magnesium sulphate & $\mathrm{MgSO}_{4} 7 \mathrm{H}_{2} \mathrm{O}$ & $\mathrm{Mg}: 10 ; \mathrm{S}: 13$ & 335 \\
\hline Ammonium sulphate & $\left(\mathrm{NH}_{4}\right)_{2} \mathrm{SO}_{4}$ & $\mathrm{~N}: 21 ; \mathrm{S}: 24$ & 754 \\
\hline Potassium chloride & $\mathrm{KCl}^{2}$ & K: $60 ; \mathrm{Cl}: 48$ & 330 \\
\hline
\end{tabular}

Table 4. Fertilizers containing macronutrients that are commonly used in the preparation of nutrient solutions.

\section{Conclusion and prospects}

The fundamental component in hydroponic system is represented by the nutrient solution. The control of nutrient solution concentration, referred as electrical conductivity or osmotic pressure, allows the culture of a great diversity of species. Moreover, the accurate control of nutrient supply to the plant represents the main advantage of soilless culture. Additionally, the regulation of $\mathrm{pH}$, root temperature among others factors, leads to increased yield and quality.

Hydroponics is a versatile technology, appropriate for both village or backyard production systems to high-tech space stations. Hydroponic technology can be an efficient mean for food production from extreme environmental ecosystems such as deserts, mountainous regions, or arctic communities. In highly populated areas, hydroponics can provide locally grown high-value crops such as leafy vegetables or cut flowers.

The future use of controlled environment agriculture and hydroponics must be costcompetitive with those of open field agriculture. Therefore, associated technologies such as artificial lighting, plastics, and new cultivars with better biotic and abiotic resistance will increase crop yields and reduce unit costs of production.

Prospects for hydroponics may improve if governments design public policies supporting subsidies for such production systems. Besides economic benefits, hydroponics implies conservation of water, cogeneration of energy, income-producing employment for, reducing the impact on welfare rolls and improving the quality of life.

Nowadays, development and use of hydroponics has enhanced the economic well- being of many communities both in developing and developed countries. 


\section{References}

Andriolo, J. L.; Godoi, R. S.; Cogo, C. M.; Bortolotto, O. C.; Luz, G. L. \& Madaloz, J. C. (2006). Growth and Development of Lettuce Plants at High $\mathrm{NH}_{4}{ }^{+}: \mathrm{NO}_{3}{ }^{-}$Ratios in the Nutrient Solution. Horticultura Brasileira, Vol.24, No.3, (Jul-Set 2006), pp. 352-355, ISSN 0102-0811

Ansorena, J. (1994). Sustratos. Propiedades y Caracterización. Mundi-Prensa, ISBN 978-84-7114481-2, Madrid, España

Ayers, C. J. \& Westcot, D. W. (1987). La Calidad del Agua en la Agricultura. FAO. Serie Riego y Drenaje No. 29. Roma, Italia.

Bishop, M.M; Shahid, N.; Yang, J. \& Barron, A. (2004) Determination of the Mode and Efficacy of the Cross-Linking of Guar by Borate Using MAS 11B NMR of Borate Cross-Linked Guar in Combination with Solution 11B NMR of Model Systems, Dalton Transactions, Vol.2004,No. 17, pp. 2621-2634, ISSN 0300-9246

Bonachela, S.; Acuña, R. A.; Magan, J. J. \& Malfa, O. (2010). Oxygen Enrichment of Nutrient Solution of Substrate-Grown Vegetable Crops under Mediterranean Greenhouse Conditions: Oxygen Content Dynamics and Crop Response. Spanish Journal of Agricultural Research, Vol.8, No.4, (Dec 2010), pp. 1231-1241, ISSN: 1695-971-X

Breteler, H. \& Smith, A. L. (1974). Effect of Ammonium Nutrition on Uptake and Metabolism of Nitrate in Wheat. Netherlands Journal of Agricultural Science, Vol.22, No.1, (Jan 1974), pp. 73 - 81, ISSN 0028-2928.

Brun, R.; Settembrino, A. \& Couve, C. (2001). Recycling of Nutrient Solutions for Rose (Rosa hybrida) in soilless culture. Acta Horticulturae, Vol.554, No.1, (Jun 2001), pp. 183192..ISSN 0567-7572

Bugbee, B. (2004). Nutrient Management in Recirculating Hydroponic Culture, Acta Horticulturae, Vol. 648, No.1, (Feb 2004), pp. 99 - 112, ISSN $0567-7572$

Calatayud, A.; Gorbe, E.; Roca D.; \& Martínez P. F. (2008). Effect of Two Nutrient Solution Temperatures on Nitrate Uptake, Nitrate Reductase Activity, $\mathrm{NH}_{4}{ }^{+}$Concentration and Chlorophyll a Fluorescence in Rose Plants. Environmental and Experimental Botany, Vol.64, No.1, (September 2008), pp. 65-74, ISSN 0098-8472

Calmin, G.; Dennler, G.; Belbahri, L.; Wigger, A. \& Lefort F. (2008). Molecular Identification of Microbial Communities in the Recycled Nutrient Solution of a Tomato Glasshouse Soil-Less Culture. The Open Horticulture Journal, Vol.1, No.1, (Jan 2008), pp. 7-14, ISSN: 18748406

Carmassi, G.; Incrocci, L.; Malorgio, M.; Tognoni, F. \& Pardossi, A. (2003). A Simple Model for Salt Accumulation in Closed-Loop Hydroponics. Acta Horticulturae, Vol.614, No.1, (September, 2003), pp. 149-154, ISSN 0567-7572

Coic, Y (1973) Les Problèmes de Composition et de Concentration des Solutions Nutritives en Culture Sans Sol, Proceedings of IWOSC 1973 3rd International Congress on Soilless Culture, pp. 158-164, Sassari, Italy, May 7-12, 1973.

Cooper, A. (1988). "1. The system. 2. Operation of the system". In: The ABC of NFT. Nutrient Film Technique, 3-123, Grower Books (ed.), ISBN 0901361224, London, England.

Charidin, Y.; Suhardiyano, H. \& Matsuoka, T. 2006. Application of Deep Sea Water for Nutrient Cooling System in Hydroponic Culture, Proceedings of APAARI the International Symposium on Sustainable Agriculture in Asia, pp. 1-4, Bogor, Indonesia, September 18-21, 2006. 
Chadirin, Y.; Matsuoka, T.; Suhardiyanto, H. \& Susila. A. D. (2007). Application of Deep Sea Water (DSW) for Nutrient Supplement in Hydroponics Cultivation of Tomato: Effect of supplemented DSW at Different EC Levels on Fruit Properties. Bulletin Agronomy, Vol.35, No.2, pp. 118 - 126, ISSN 216-3403

Chun, C. \& Takakuta, T. (1994). Rate of Root Respiration of Lettuce under Various Dissolved Oxygen Concentrations in Hydroponics. Environment Control in Biology, Vol.32, No.2, (Apr 1994), pp. 125-135, ISSN 1883-0986

Dalton, F. N.; Maggio, A. \& Piccinni, G. (1997). Effect of Root Temperature on Plant Response Functions for Tomato: Comparison of Static and Dynamic Salinity Stress Indices. Plant and Soil, Vol. 192, No.2, (May 1997), pp. 307-319, ISSN 0032-079X

De Rijck G. \& Schrevens E. (1997) pH Influenced by the Elemental Composition of Nutrient Solutions. Journal of Plant Nutrition, Vol.20, No.7-8, (Jul 1997) 911-923. ISSN. 01904167

De Rijck G.; Schrevens E. (1998a) Cationic Speciation in Nutrient Solutions as a Function of pH. Journal of Plant Nutrition, Vol.21, No.5 (May 1998), pp. 861-870, ISSN. 0190-4167

De Rijck, G. \& Schrevens, E. (1998b). Elemental bioavailability in nutrient solutions in relation to complexation reactions. Journal of Plant Nutrition, Vol.21, No.10, (Oct 1998), pp. 2103-2113, ISSN 0190-4167.

De Rijck G. \& Schrevens E (1998c) Comparison of the Mineral Composition of Twelve Standard Nutrient Solutions. Journal of Plant Nutrition, Vol.21, No.10, (Oct 1998), pp. 2115-2125. ISSN 0190-4167

De Rijck G. \& Schrevens, E. (1999) Anion Speciation in Nutrient Solutions as a Function of pH Journal of Plant Nutrition, Vol.22, No.2, (Feb 1999), pp. 269-279. ISSN 0190-4167

Dufour, L. \& Guérin, V. (2005). Nutrient Solution Effects on the Development and Yield of Anthurium andreanum Lind. in Tropical Soilless Conditions. Scientia Horticulturae, Vol.105, No.2, (Jun 2005), pp. 269-282, ISSN 0304-4238

Dyśko, J. ; Kaniszewski, S. \& Kowalczyk, W. (2008). The Effect of Nutrient Solution pH on Phosphorus Availability in Soilless Culture of Tomato. Journal of Elementology, Vol. 13, No.2, (Jun 2008), pp. 189-198, ISSN 1644-2296

Falah, M. A. F.; Wajima, T.; Yasutake, D.; Sago, Y. \& Kitano, M. (2010). Responses of Root Uptake to High Temperature of Tomato Plants (Lycopersicon esculentum Mill.) in Soil-less Culture. Journal of Agricultural Technology, Vol.6, No.3, (Jul 2010), pp. 543558, ISSN 1686-9141

Fanasca, S.; Colla, G.; Maiani, G.; Venneria, E.; Rouphael, Y.; Azzini, E. \& Saccardo, F. (2006). Changes in Antioxidant Content of Tomato Fruits in Response to Cultivar and Nutrient Solution Composition. Journal of Agricultural and Food Chemistry, Vol.54, No. 12, (Jun 2006), pp. 4319-4325, ISSN 0021-8561

Farina, E.; Allera, C.; Paterniani, T. \& Palagi, M. (2003). Mulching as a Technique to Reduce Salt Accumulation in Soilless Culture. Acta Horticulturae, Vol.609, No.1, (May 2003), pp. 459-466, ISSN 0567-7572

Chen, F.; He, H. \& Tang, Y. (2011). In-situ Optimal Control of Nutrient Solution for Soilless Cultivation, Proceedings of ICACC $20113^{\text {rd }}$ International Conference on Advanced Computer Control, pp. 412-416, Harbin, China, Jan 18-20, 2011.

Gislerød, H. R. \& Adams, P. (1983). Diurnal Variations in the Oxygen Content and Requirement of Recirculating Nutrient Solutions and in the Uptake of Water and 
Potassium by Cucumber and Tomato Plants. Scientia Horticultura, Vol.21, No.4, (Dec 1983), pp. 311-321, ISSN 0304-4238

Graves, C. J. (1983). The Nutrient Film Technique. Horticultural Reviews, Vol.5, No.1, (Jan 1983), pp. 1-44, ISSN 978-0-470-38642-2

Gruda, N. (2009). Do Soilles Culture Systems have an Influence on Product Quality of Vegetables? Journal of Applied Botany and Food Quality, Vol.82, No.2, pp. 141-147, ISNN 1613-9216

Hansen, M. (1978). Plant Specific Nutrition and Preparation of Nutrient Solutions. Acta Horticulturae, Vol.82, No.1, (Apr 1978), pp. 109-112, ISSN 0567-7572

Hewitt, E. J. (1996). Sand and Water Culture Methods Used in the Study of Plant Nutrition. Technical Communication No. 22. Commonwealth Bureau of Horticulture and Plantation Crops, East Malling, Maidstone, Kent, England

Hidaka, K.; Kitano, M.; Sago, Y.; Yasutake, D.; Miyauchi, K.; Affan, M. F. F.; Ochi, M. \& Imai, S. (2008). Energy-Saving Temperature Control of Nutrient Solution in Soil-Less Culture Using an Underground Water Pipe. Acta Horticulturae, Vol.797. No.1, (Sep 2008), pp. 185-191, ISSN 0567-7572

Jensen, M. H. \& Collins, W. L. (1985). Hydroponic Vegetable Production. Horticultural Reviews, Vol.7, pp. 483- 559, ISSN 9780870554926

Juárez H., M. J.; Baca C., G. A.; Aceves N., L. A.; Sánchez G., P.; Tirado T., J. L.; Sahagún C., J. \& Colinas D. L., M. T. (2006). Propuesta para la Formulación de Soluciones Nutritivas en Estudios de Nutrición Vegetal. Interciencia, Vol.31, No.4, (Apr 2006), ISSN 0378-1844

Kang, J. G. \& van Iersel, M. W. (2004). Nutrient Solution Concentration Affects Shoot: Root Ratio, Leaf Area Ratio, and Growth of Subirrigated Salvia (Salvia splendens). HortScience, Vol.39, No.1, (Feb 2004), pp. 49-54, ISSN 0018-5345

Landowne, D. (2006). Cell Physiology, McGraw-Hill Medical Publishing Division, ISBN 0071464743, Miami, FL., U. S. A.

Lorenzo, H.; Cid, M. C; Siverio, J. M. \& Caballero, M. (2000). Influence of Additional Ammonium Supply on Some Nutritional Aspects in Hydroponic Rose Plants. The Journal of Agricultural Science, Vol.134, No.4, (Sep, 2000), pp. 421-425, ISSN 00218596

Lykas, C. H.; Giaglaras, P. \& Kittas, C. (2001). Nutrient Solution Management Recirculating Soilless Culture of Rose in Mild Winter Climates. Acta Horticulturae, Vol.559, No.1, (Oct 2001), pp. 543-548, ISSN 0567-7572

Macfie, S. M. \& Taylor, G. J. (1989). The Effects of $\mathrm{pH}$ and Ammonium on the Distribution of Manganese in Triticum aestivum Grown in Solution Culture. Canadian Journal of Botany, Vol.67, No.11, (Nov 1989), pp. 3394-3400 ISSN 0008-4026

Marschner, H. (1995). Mineral Nutrition of Higher Plants, Academic Press, ISBN 0-12-473542-8, New York, U. S. A.

Morard, P. \& Silvester, J. (1996). Plant Injury Due to Oxygen Deficiency in the Root Environment of Soilless Culture: A Review. Plant and Soil, Vol.184, No.2, pp. 243254, ISBN 0032-079X

Nam, S. W.; Kim, M. K. \& Son, J. E. (1996). Nutrient Solution Cooling and its Effect on Temperature of Leaf Lettuce in Hydroponic System. Acta Horticulturae, Vol.440, No. 1, (Dec 1996), pp.: 227-32. ISSN 0567-7572 
Nxawe, S.; Laubscher, C. P. \& Ndakidemi, P. A. (2009). Effect of Regulated Irrigation Water Temperature on Hydroponics Production of Spinach (Spinacia oleracea L). African Journal of Agricultural Research, Vol.4, No.12, (December, 2009), pp. 1442-1446, ISSN 1991- 637X

Nemali, K. S. \& van Iersel, M. W. (2004). Light Intensity and Fertilizer Concentration: I. Estimating Optimal Fertilizer Concentration from Water-Use Efficiency of Wax Begonia. HortScience, Vol.39, No.6, (Oct 2004), pp. 1287-1292. ISSN 0018-5345

Papadopoulous, A. P.; Hao., X.; Tu, J. C. \& Zheng, J. (1999). Tomato Production in Open or Closed Rockwool Culture Systems with NFT or Rockwool Nutrient Feedings. Acta Horticulturae, Vol.481. No.1, (Jan 1999), pp. 89-96, ISSN 0567-7572

Pardossi, A.; Incrocci, L.; Massa, D.; Carmassi, G. \& Maggini, R. (2009). The Influence of Fertigation Strategies on Water and Nutrient Efficiency of Tomato Grown in Closed Soilless Culture with Saline Water. Acta Horticulturae, Vol.807, No.2, (Jan 2009), pp. 445-450, ISSN 0567-7572

Resh, H. M. (2004). Hydroponic Food Production, Newconcept Press, Inc., ISBN-10: 093123199X, Mahwah, NJ., U. S. A.

Rouphael, Y.; Colla, G., (2009). The Influence of Drip Irrigation or Subirrigation on Zucchini Squash Grown in Closed-Loop Substrate Culture with High and Low Nutrient Solution Concentrations. HortScience, Vol.44, No.2, (Apr 2009), pp. 306-311, ISSN 0018-5345

Salisbury, F. B. \& Ross, C. W. (1992). Plant Physiology. Wadsworth Publishing Company, ISBN 0-534-15162-0, California, U. S. A.

Samarakoon, U.C.; Weerasinghe, P. A. \& Weerakkody, A. P. (2006). Effect of Electrical Conductivity [EC] of the Nutrient Solution on Nutrient Uptake, Growth and Yield of Leaf Lettuce (Lactuca sativa L.) in Stationary Culture. Tropical Agricultural Research, Vol.18, No. 1, (Jan 2006), pp. 13-21 ISSN 1016.1422

Sandoval V., M.; Sánchez G., P. \& Alcántar G., G. (2007). Principios de la Hidroponía y del Fertirriego, In: Nutrición de Cultivos, G. Alcántar G \& L. I. Trejo-Téllez, L. I. (Eds.), 374-438, Mundi-Prensa, ISBN 978-968-7462-48-6, México, D. F., México.

Siddiqi, M. Y.; Kronzucher, H. J.; Britto, D. T. \& Glass, A. D. M. (1998). Growth of a Tomato Crop at Reduced Nutrient Concentrations as a Strategy to Limit Eutrophication. Journal of Plant Nutrition, Vol.21, No.9, (Sep 1998), pp. 1879-1895. ISSN 0190-4167

Steiner, A. A. (1961). A Universal Method for Preparing Nutrient Solutions of a Certain Desired Composition. Plant and Soil, Vol.15, No.2, (October, 1961), pp. 134-154, ISBN 0032-079X

Steiner, A. A. (1966). The Influence of Chemical Composition of a Nutrient Solution on the Production of Tomato Plants. Plant and Soil, Vol.24, No.3, (June1966), pp. 454-466, ISBN 0032-079X

Steiner, A.A. (1968). Soilless Culture, Proceedings of the IPI 1968 6th Colloquium of the Internacional Potash Institute, pp: 324-341, Florence, Italy

Steiner, A. A. (1973). The Selective Capacity of Tomato Plants for Ions in a Nutrient Solution, Proceedings of IWOSC 1973 3rd International Congress on Soilless Culture, pp. 43-53, Sassari, Italy, May 7-12, 1973

Steiner, A. A. (1984). The Universal Nutrient Solution, Proceedings of IWOSC 1984 6th International Congress on Soilless Culture, pp. 633-650, ISSN 9070976048, Wageningen, The Netherlands, Apr 29-May 5, 1984 
Sonneveld, C. \& Voogt, W. (2009). Plant Nutrition of Greenhouse Crops, Springer, ISBN 9048125316, New York, U. S. A.

Taiz, L. \& Zeiger, E. (1998). Plant Physiology. Sinauer Associates, Inc. Publishers. Sunderland, ISBN : 0878938311, Massachusetts, U. S. A.

Tanji, K. K. (1990). Agricultural salinity assessment and management. American Society of Civil Engineers, ISBN-10: 0872627624, New York, U. S. A.

Tariq, M. \& Mott, C. J. B. (2007). The Significance of Boron in Plant Nutrition an environment-A Review. Journal of Agronomy, Vol.6, No.1, (Jan 2007), pp. 1-10, ISSN 1812-5379

Timmons, M. B; Ebeling, J. M.; Wheaton, F. W.; Summerfelt, S. T. \& Vinci, B. J. (2002). Recirculating aquaculture systems. Cayuga Aqua Ventures, ISBN 0-9712646-1-9, Ithaca, NY.

Tognoni, F.; Pardossi, A. \& Serra, G. (1998). Water Pollution and the Greenhouse Environmental Costs. Acta Horticulturae, Vol.458, No.1, (Apr 1998), pp. 385-394, ISSN 0567-7572

Trejo-Téllez, L. I.; Gómez-Merino, F. C. \& Alcántar G., G. (2007). Elementos Benéficos, In: Nutrición de Cultivos, G. Alcántar G \& L. I. Trejo-Téllez, L. I. (Eds.), 50-91, MundiPrensa, ISBN 978-968-7462-48-6, México, D. F., México

Tyson, R. V. (2007). Reconciling $\mathrm{pH}$ for Ammonia Biofiltration in a Cucumber/Tilapia Aquaponics System Using a Perlite Medium. Journal of Plant Nutrition, Vol.30, No.6, (Jun 2007), pp. 901-913, ISSN 0190-4167

Tyson, R. V.; Simonne, E. H.;Davis, M.; Lamb, E. M.; White, J. M. \& Treadwell, D. D. (2007). Effect of Nutrient Solution, Nitrate-Nitrogen Concentration, and $\mathrm{pH}$ on Nitrification Rate in Perlite Medium. Journal of Plant Nutrition, Vol.30, No.6, (Jun, 2007), pp. 901-913, ISSN 0190-4167

Urrestarazu, M. (2004). Tratado de Cultivo sin Suelo. Mundi-prensa, ISBN 84-8476-139-8, Madrid, España

Urrestarazu, M. \& Mazuela, P. C. (2005). Effect of Slow-Release Oxygen Supply by Fertigation on Horticultural Crops under Soilless Culture. Scientia Horticulturae, Vol. 106, No.4, (November 2005), pp. 484-490, ISSN 0304-4238

USDA. (2001). Soil Quality Test Kit Guide. Natural Resources Conservation Service. Washington, D. C., U. S. A.

Van Labeke, M. C.; Dambre, P.; Schrevens. E. \& De Rijck G. (1995) Optimisation of the Nutrient Solution for Eustoma glandiflorum in Soilless Culture. Acta Horticulturae, Vol.401, No.1, (Oct 1995), pp. 401-408, ISSN 0567-7572

Van Os, E. A. (2010). Disease Management in Soilless Culture Systems. Acta Horticulturae, Vol.883, No.1, (Nov 2010), pp. 385-393, ISSN 0567-7572

Villela, J.; Luiz, V. E.; Araujo, J. A. C. de \& Factor, T. L. (2004). Nutrient Solution Cooling Evaluation for Hydroponic Cultivation of Strawberry Plant. Engenharia Agrícola, Vol.24, No.2, (May-Aug 2004), pp. 338-346, ISSN 0100-6916

Voogt, W. (2002). Potassium management of vegetables under intensive growth conditions, In: Potassium for Sustainable Crop Production. N. S. Pasricha \& S. K. Bansal SK (eds.), 347-362, International Potash Institute, Bern, Switzerland.

Windsor, G. \& Schwarz, M. (1990). Soilless Culture for Horticultural Crop Production. FAO, Plant Production and Protection. Paper 101. Roma, Italia. 
Zekki, H.; Gauthier, L. \& Gosselin A. (1996). Growth, Productivity and Mineral Composition of Hydroponically Cultivated Greenhouse Tomatoes, With or Without Nutrient Slution Recycling. Journal of the American Society for Horticultural Science, Vol.121, No.6, (Nov 1996), pp. 1082-1088, ISSN 0003-1062

Zheng, Y.; Graham, T. H.; Richard, S. \& Dixon, M., (2005). Can Low Nutrient strategies be Used for Pot Gerbera Production in Closed-Loop Subirrigation? Acta Horticulturae, Vol.691, No.1, (October 2005), pp. 365-372. ISSN 0567-7572 


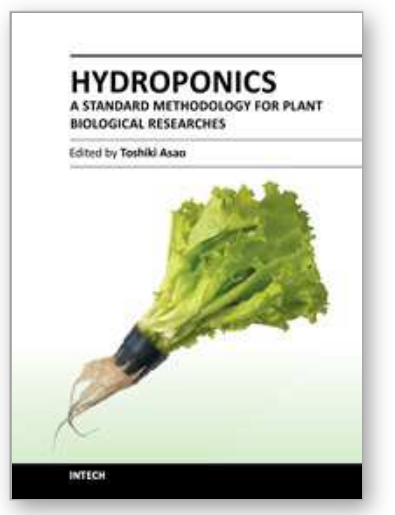

\section{Hydroponics - A Standard Methodology for Plant Biological Researches}

Edited by Dr. Toshiki Asao

ISBN 978-953-51-0386-8

Hard cover, 244 pages

Publisher InTech

Published online 23, March, 2012

Published in print edition March, 2012

Hydroponics-A standard methodology for plant biological researches provides useful information on the requirements and techniques needs to be considered in order to grow crops successfully in hydroponics. The main focuses of this book are preparation of hydroponic nutrient solution, use of this technique for studying biological aspects and environmental controls, and production of vegetables and ornamentals hydroponically. The first chapter of this book takes a general description of nutrient solution used for hydroponics followed by an outline of in vitro hydroponic culture system for vegetables. Detailed descriptions on use of hydroponics in the context of scientific research into plants responses and tolerance to abiotic stresses and on the problems associated with the reuse of culture solution and means to overcome it are included. Some chapters provides information on the role of hydroponic technique in studying plant-microbe-environment interaction and in various aspects of plant biological research, and also understanding of root uptake of nutrients and thereof role of hydroponics in environmental clean-up of toxic and polluting agents. The last two chapters outlined the hydroponic production of cactus and fruit tree seedlings. Leading research works from around the world are brought together in this book to produce a valuable source of reference for teachers, researcher, and advanced students of biological science and crop production.

\section{How to reference}

In order to correctly reference this scholarly work, feel free to copy and paste the following:

Libia I. Trejo-Téllez and Fernando C. Gómez-Merino (2012). Nutrient Solutions for Hydroponic Systems, Hydroponics - A Standard Methodology for Plant Biological Researches, Dr. Toshiki Asao (Ed.), ISBN: 978953-51-0386-8, InTech, Available from: http://www.intechopen.com/books/hydroponics-a-standardmethodology-for-plant-biological-researches/nutrient-solutions-for-hydroponic-systems

\section{INTECH}

open science | open minds

\author{
InTech Europe \\ University Campus STeP Ri \\ Slavka Krautzeka 83/A \\ 51000 Rijeka, Croatia \\ Phone: +385 (51) 770447 \\ Fax: +385 (51) 686166 \\ www.intechopen.com
}

\author{
InTech China \\ Unit 405, Office Block, Hotel Equatorial Shanghai \\ No.65, Yan An Road (West), Shanghai, 200040, China \\ 中国上海市延安西路65号上海国际贵都大饭店办公楼 405 单元 \\ Phone: +86-21-62489820 \\ Fax: +86-21-62489821
}


(C) 2012 The Author(s). Licensee IntechOpen. This is an open access article distributed under the terms of the Creative Commons Attribution 3.0 License, which permits unrestricted use, distribution, and reproduction in any medium, provided the original work is properly cited. 